\title{
Bond Pricing Before and after EMU From the Experience of the "European South"
}

\author{
Angelos A. Antzoulatos \\ University of Piraeus \\ Eleni Klinaki \\ National Bank Greece
}

\begin{abstract}
We use an extensive sample of 763 bonds issued by financial institutions of three countries of the "European South", in 1997, one year before the selection of the "first-wave" EMU participants, and in 1999, EMU's starting year, to investigate the extent to which the aforementioned expectations materialized. The empirical results indicate that, indeed, the bond market segmentation due to the different currencies was largely eliminated. In addition, the segmentation due to the different countries was reduced significantly, while the importance of credit ratings increased. The empirical results highlight the likely developments in the bond markets of countries aspiring to join the EMU.
\end{abstract}

- JEL Classification: F36, G15

- Key Words: Bonds, Credit Ratings, EMU, Market Segmentation

\section{Introduction}

As Dr. Jürgen Stark, Deputy Governor of the Bundesbank, stresses (Stark, 1999), Euro's introduction and the attendant elimination of foreign exchange risk were expected to bring profound changes to the European capital markets. Among these changes, they were expected to lead to a broader, deeper and more

\footnotetext{
*Corresponding address: Department of Banking \& Financial Management, University of Piraeus, 80 Karaoli \& Dimitriou street, Piraeus 18534 Greece

Tel.: +301-414-2185, Fax.: +301-414-2341, E-mail: antzoul@unipi.gr

(O)2002-Center for International Economics, Sejong Institution, All Rights Reserved.
} 
liquid bond market, covering the whole of the Euro-area, in which the cost of borrowing would reflect credit and liquidity risk to a greater degree than before. In addition, it would lead to more intense competition among EMU governments for funds, by eliminating their monopolies in the domestic bond markets, and reduce the returns of government bonds. The latter would induce investors to seek alternative investments, leading as a result, to higher demand for bonds issued by private entities. As for the borrowing entities, they would seek to be rated by credit rating agencies, so that their bonds could compete more effectively with those of American corporations the majority of which are rated.

Essentially, the aforementioned expected changes were signalling the gradual development of an integrated European bond market, with a parallel increase in the role of credit rating agencies, something that many informed observers besides Dr Stark had stressed (see, for example the Financial Times, 30/11/98). The importance of these agencies, it should be noted, had been rising during the previous decade, as a result of the growing demand for credit ratings. To this demand contributed, among other developments, the growing presence of Emerging Markets in the international financial markets and the massive capital flows into them (Larrain et al., 1997); the proposed incorporation of credit ratings into bank capital adequacy rules (BIS [1999b], IMF [1999b]); and the restrictions on institutional investors (mutual funds, insurance companies, pension funds) regarding the inclusion in their portfolios of speculative-grade (as opposed to investment-grade) assets (Cantor and Packer, 1994).

This paper explores empirically the extent to which the aforementioned expectations have materialized so far. To this end, it uses an extensive sample of 763 bonds issued in 1997 and 1999, by financial institutions of Italy, Portugal and Spain. These particular years and countries were chosen with the explicit goal to evaluate as best as possible the impact of Euro's introduction. Specifically, in 1997 the three countries were not certain to participate to the "first wave" of EMU in contrast to the countries of the "European North". In addition, the exchange rate risk had not been eliminated, for the conversion parities of domestic currencies to Euro had not been announced yet. As a result, the expected changes due to Euro's introduction had not occurred yet, especially for the three sample countries, in contrast to 1999, when the uncertainties regarding EMU participation and conversion parities had been resolved. 


\section{Data}

The data on individual bonds comes mostly from Bloomberg. Bloomberg provides information about the type of the issuer (governments central and local, financial institutions, corporations), the currency and amount of issuance, the issuance and maturity date, the type of the bond (zero coupon, fixed rate, floating rate, etc.), plus the credit ratings provided by Moody's, Standard \& Poor's, and Fitch IBCA. In addition, the databases of Bankscope, and Reuters 3000 Fixed Income, as well as publications of the three credit-rating agencies, were used for those bonds for which Bloomberg did not provide a rating.

The sample includes bonds of maturity of one year or more that meet a specific criterion: they do not have characteristics like callable, putable, sinkable, equity linked (convertibles, bonds with warrants, etc.), whose effect on the cost of borrowing is difficult to quantify. Illustrating this difficulty, there were bonds linked to the performance of a soccer team in domestic and international championships. The criterion was satisfied by 255 bonds in 1997 and 677 in 1999. From these, 602 (96 in 1997 and 506 in 1999) were issued by Italian entities, 170 $(43+127)$ by Spanish and $60(16+44)$ by Portuguese.

As Figure 1 indicates, financial institutions were the biggest issuers in both years, with a share of $79 \%$ in 1997 and $85 \%$ in 1999. At a distance followed central governments, whose share by the way shrunk from $15 \%$ in 1997 to just $8 \%$ in 1999. The share of corporate and local government bonds was very small and rather stable.

In addition, in 1997 the vast majority of bonds was issued in domestic currency

Figure 1. Sample Composition-Borrowing Entities

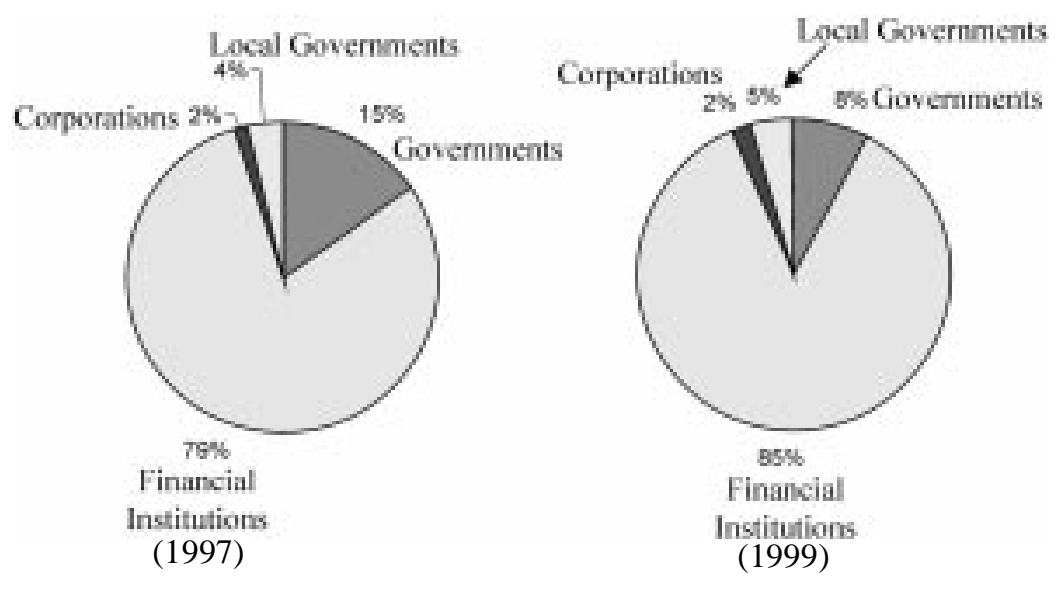


(75\% of the total), 16\% in ECU-Euro's predecessor, and 9\% in other currencies (Figure 2). In 1999, however, the vast majority was in Euro's, $77 \%$ of total, $20 \%$ in domestic currency and 3\% in other currencies. Among these currencies are the U.S.A. dollar (5 issues in 1997 and 10 in 1999), the German mark ( 2 and 0 issues), the French franc ( 2 and 0 ), the Japanese yen ( 3 and 0$)$, the British pound ( 0 and 5 ), and the Greek drachma (0 and 7).

Figure 2. Sample Composition--Currency of Inssuance
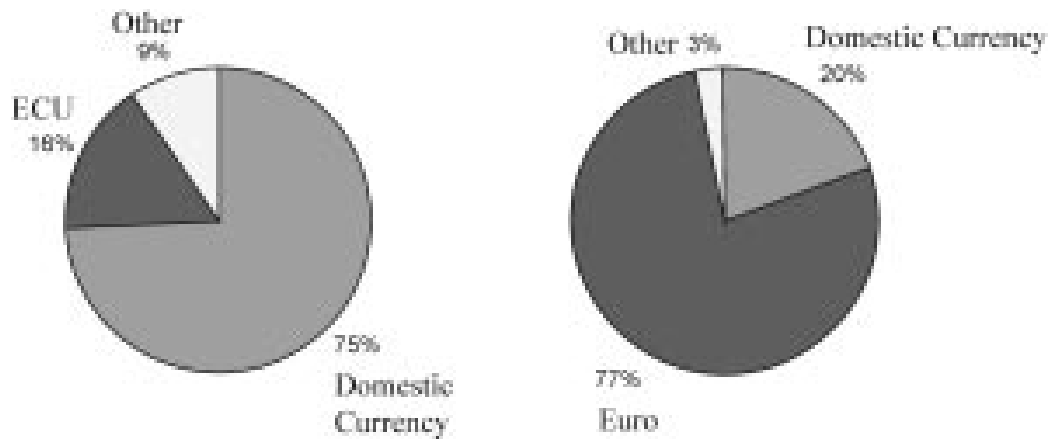

Last but not least, all the bonds issued in both years were "investment grade" (Figure 3) and thus there was no restriction on institutional investors for any of them. Specifically, the lowest credit rating was Baal in the scale of Moodys or $B B B$ - in the scale of Standard\&Poors and Fitch IBCA.

Figure 3. Sample Composition--Credit Ratings
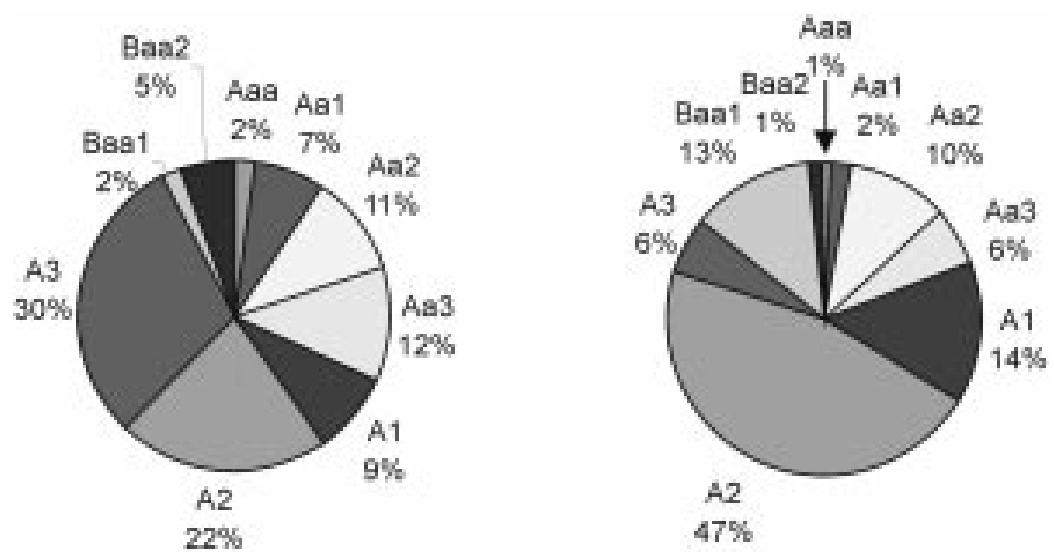

Taking into account that the biggest share of the bonds was issued by financial institutions (79\% in 1997 and 85\% in 1999), in ECU/Euro and domestic currency (91\% in 1997 and 97\% in 1999), and aiming at reducing the number of bond characteristics and the attendant number of dummy variables-details are provided 
below, we include in the sample bonds issued by the aforementioned institutions in ECU/Euro and domestic currency. Indicatively, the usage of a dummy variable for each of the other currencies would be meaningless: owing to the small number of observations, their coefficients could not be estimated. A similar problem applies to dummy variables for bonds issued by corporations and local governments. Yet, despite this reduction in the number of bonds, the final sample includes enough observations, 198 in 1997 and 565 in 1999, for a meaningful econometric estimation.

\section{Methodology}

The cost of borrowing is postulated to be a function of the characteristics of the country of the borrowing financial institution and of the bonds themselves (see, for example, Edwards (1984), Eichengreen and Mody (2000), and Antzoulatos (2000)). It is usually expressed as the spread of the yield to maturity at issuance over the 6-month LIBOR of the currency of issue at the day of issuance. The spread, essentially, takes into account the (occasionally) big difference in the interest rates of different currencies which is due to the possibility of exchange rate changes. The yield to maturity was estimated using the price of issuance, the coupon and the maturity, applying the standard formulas. As for the LIBOR rates, they were retrieved from Datastream. Lastly, the spread is expressed in basis points (100 basis points $=1 \%)$.

Three dummy variables, the descriptively named ITALY, SPAIN and PORT, are used for the characteristics of the three sample countries. If a particular bond was issued by an Italian financial institution, it is set $I T A L Y=1$ and $S P A I N=P O R T=0$. SPAIN and PORT are defined in a similar way. By construction, ITALY + SPAIN $+P O R T=1$.

As for the characteristics of the bonds, they include:

- The currency of issuance. Following Eichengreen and Mody (2000), it is captured by two dummy variables: OWNCURR and EURO. When a bond is issued in the domestic currency of the borrowing institution, $O W N C U R R=1$ and $E U R O=0$. Similarly, when a bond is issued in ECU (in 1997) or Euro (in 1999), $E U R O=1$ and $O W N C U R R=0$. By construction, again, OWNCURR+ $E U R O=1$.

- Credit risk. This is captured by the credit rating. Following Cantor and Packer (1996), the alphanumeric ratings were converted to a numerical scale. 
Specifically, the lowest investment-grade rating ( $B 3$ in Moody's scale and $B$ in Standard \& Poor's and Fitch IBCA's scales) was assigned the value 1 of the variable CREDIT, the next grade was assigned the value 2, and so on, with the highest ratings (Aaa in Moody's scale and $A A A$ in the other two scales) assigned the value of 16 . The coefficient of CREDIT is expected to be negative, for a higher credit rating is ceteris paribus associated with lower cost of borrowing (and lower spread).

- The maturity of the bond, variable MATUR, in years. Greater maturity is associated with higher borrowing cost, hence the coefficient of this variable is expected to be positive.

- The amount of the issue, AMOUNT. On the demand side, a higher amount may be associated with a higher spread, in order to induce investors to buy all the floated bonds. On the supply side, however, a lower cost may encourage the issuance of more bonds. Owing to these opposing forces, the sign of the coefficient of this variable is not known a priori. AMOUNT is expressed in a common currency, U.S. dollars, using the exchange rates on the date of issuance from Datastream. As a validity check, the logarithm of the variable AMOUNT is also used. In this way, the scale of this variable is brought closer to that of the other variables. A similar transformation was also used by Eichengreen and Mody (2000), who, by the way, found a negative sign for its coefficient.

The above suggest the testable equation below, in which $a, b_{1}, b_{2}, b_{3}, c_{1}, c_{2}, d$, $e$, and $f$ are the unknown coefficients. From those, $d$ is expected to be negative, $e$ positive, while the sign of the others is not known a priori.

$$
\begin{aligned}
S P R E A D= & a+b_{1} I T A L Y+b_{2} S P A I N+b_{3} \text { PORT }+c_{1} \text { OWNCURR }+c_{2} \text { EURO } \\
& +d \text { CREDIT }+e \text { MATUR }+f \text { AMOUNT }
\end{aligned}
$$

To tackle the multicollinearity problem caused by that ITALY+SPAIN+PORT $=1$ and $O W N C U R R+E U R O=1$, the equation is transformed to

$$
\begin{aligned}
\text { SPREAD }= & \left(a-b_{1}-c_{1}\right)+\left(b_{2}-b_{1}\right) S P A I N+\left(b_{3}-b_{1}\right) P O R T+\left(c_{2}-c_{1}\right) E U R O+ \\
& d \text { CREDIT }+e \text { MATUR }+f \text { AMOUNT } \\
= & \alpha+\beta_{2} \text { SPAIN }+\beta_{3} \text { PORT }+\gamma_{2} \text { EURO }+d \text { CREDIT }+e \text { MATUR } \\
& +f \text { AMOUNT }
\end{aligned}
$$

which provides the basis for the econometric analysis. In it, $a=a-b_{1}-c_{1}, \beta_{2}=b_{2}-b_{1}$, $\beta_{3}=b_{3}-b_{1}, \gamma_{2}=c_{2}-c_{1}, \delta=d, \varepsilon=e$ and $\phi=f$. 
Absent from the above equation are variables that have been used in similar studies with data from developing countries, such as, foreign exchange reserves and proxies for macroeconomic stability of the countries of the borrowing institutions (see, among others, Antzoulatos (2000)). This absence is justified by the fact that a balance of payments crisis, against which reserves would provide some reassurance to international investors, or macroeconomic instability are not pressing issues for developed countries that weigh in the minds of investors, while they are indeed for developing ones.

Market segmentation due to the different countries would be manifested in $\beta_{2}=$ $\left(b_{2}-b_{1}\right) \neq 0$. If it turns out that $\beta_{2}>0$, this would mean that, for the same bond characteristics and currency, Spanish financial institutions had a higher borrowing cost (spread) than their Italian counterparts, and vice-versa. The same applies to Portuguese financial institutions when $\beta_{3}=\left(b_{3}-b_{1}\right)>0$. The main factors related to the country of the borrowing institution that differentiates the cost of borrowing are the liquidity of the respective domestic markets-higher liquidity is associated with lower cost and the country risk associated in 1997 with the probability of the country's (non) inclusion in EMU's "first wave". Though liquidity is a multifaceted concept that cannot be readily quantified (BIS, 1999a), in this particular case Italy's much higher issuance volume and economic size suggest that liquidity was higher for this country. As for the second factor, Portugal was in 1997 closer to meeting the Maastricht Treaty criteria than the other two countries.

Next, market segmentation due to the currency of issuance would be manifested in $\gamma_{2}=\left(c_{2}-c_{1}\right) \neq 0$. In this case, $\gamma_{2}<0$ would indicate lower cost of borrowing in ECU/Euro than in local currency, most likely owing to the relatively larger size and higher liquidity of the ECU/Euro market segment relative to that of the domestic currency segment. In the opposite case, that is, $\gamma_{2}>0$, investors in each country, possibly due to the then existing institutional restrictions and the exchange rate risk, preferred domestic-currency bonds and were willing to pay a higher price (get a lower yield) for them, something, however, Euro's introduction was expected to eliminate.

The above equation is estimated separately for 1997 and 1999. By comparing the results for the two years, one can evaluate the impact of Euro's introduction.

Moreover, as an additional robustness check, the equation is estimated with time dummies for the months of issuance. Specifically, for each month except December, there is a dummy variable. December's dummy is subsumed into the constant term of the equation to avoid multicollinearity. Essentially, these dummy 
variables attempt to capture the effect of time-specific events that affect all the sample countries and borrowing institutions. Such as, an increase in global liquidity which could drive down the spreads for all borrowers in the international financial markets (Antzoulatos (2000)), or LTCMs near-bankruptcy in the fall of 1999 which had the opposite effect.

\section{Results}

Table 1 summarizes the econometric results. Starting from the left, the first column presents the independent variables that are significant in at least one of the estimated equations. The second and third columns present the results for 1997 and 1999, respectively, for the basic equation. Lastly, the fourth and fifth columns present the results for the two years when the time dummies are included in the estimated equation. The numbers in parentheses below each estimated coefficient are the $t$-statistics; one $(*)$, two $(* *)$ and three $(* * *)$ asterisks denote significance

Table 1. Econometric Results

$S P R E A D=\mathrm{a}+\beta_{2} S P A I N+\beta_{3} P O R T+\beta_{2} E U R O+\delta C R E D I T+\varepsilon M A T U R+\phi A M O U N T$

\begin{tabular}{|lllll|}
\hline & \multicolumn{2}{c}{ Basic Equation } & \multicolumn{2}{c|}{$\begin{array}{l}\text { Robustness Check } \\
\text { With Time Dummies }\end{array}$} \\
\hline $\begin{array}{l}\text { Independent } \\
\text { Variables }\end{array}$ & 1997 & 1999 & 1997 & 1999 \\
\hline Constant & -75.53 & 72.45 & -40.21 & 86.07 \\
& $(-5.50)^{* * *}$ & $(2.08)^{* *}$ & $(-1.47)$ & $(2.33)^{* *}$ \\
SPAIN & 87.79 & 40.86 & 73.49 & 47.47 \\
& $(3.83)^{* * *}$ & $(3.09)^{* * *}$ & $(3.21)^{* * *}$ & $(3.57)^{* * *}$ \\
PORT & & 25.41 & & 26.39 \\
& & $(1.68)^{*}$ & & $(1.77)^{*}$ \\
EURO & 100.65 & 14.52 & 104.11 & \\
& $(3.83)^{* * *}$ & $(1.66)^{*}$ & $(3.86)^{* * *}$ & \\
CREDIT & & -8.81 & & -8.18 \\
& & $(-2.83)^{* * *}$ & & $(-2.59)^{* * *}$ \\
MATUR & 7.72 & 8.81 & 8.10 & 9.23 \\
Number of Observations & $(4.33)^{* * * *}$ & $(10.74)^{* * *}$ & $(4.41)^{* * *}$ & $(11.33)^{* * *}$ \\
$R^{2}$-adjusted & 198 & 565 & 198 & 565 \\
D.W. & 0.362 & 0.196 & 0.388 & 0.220 \\
\hline
\end{tabular}

Notes: Sources: BLOOMBERG, REUTERS 3000 Fixed Income, DATASTREAM, and publications of the three major credit-rating agencies.

The numbers in parentheses below each estimated coefficient are the t-statistics. One $(*)$, two $(* *)$ and three $(* * *)$ asterisks denote significance at the $10 \%, 5 \%$ and $1 \%$ levels. 
at the $10 \%, 5 \%$ and $1 \%$ levels, respectively.

As documented in Table 1, there existed market segmentation due to the different countries in 1997. Specifically, the borrowing cost of Spanish financial institutions exceeded that of their Italian counterparts by 87.8 basis points (b.p.) -the coefficient of the variable SPAIN 87.79 is significant at the $1 \%$ level. The Portuguese institutions had the same cost with the Italian (the variable PORT had an insignificant coefficient), an indication that Portugal's lower country risk due to the higher probability of EMU participation counterbalanced the higher liquidity of the Italian market.

In addition, there existed significant market segmentation across currencies, with the bonds issued in ECU paying 100.6 b.p. more than bonds in domestic currency (the coefficient of the variable EURO, 100.65, is significant at the $1 \%$ level). But the credit rating did not affect the borrowing cost-the coefficient of the CREDIT variable was insignificant.

Lastly, longer maturity was associated with higher cost. Specifically, the coefficient of MATUR, 7.72 significant at the $1 \%$ level, indicates that every additional year in the maturity of the bond added 7.72 b.p. to its cost. The amount of issuance, however, was not significant, nor its logarithm.

The comparison of the results for 1999 with those for 1997 speaks eloquently about the impact of Euro's introduction. To begin with, it essentially eliminated the-segmentation due to the different currencies: EURO's coefficient declined from 100.65 to just 14.52 and is marginally significant at the $10 \%$ level. In addition, the segmentation due to the different countries was reduced: The coefficient of SPAIN fell from 87.79 to 40.86 . However, the coefficient of PORT rose from zero to 25.41 -significant at the $10 \%$ level, accentuating the importance of the higher liquidity of the Italian market after the resolution of the uncertainty regarding Italys participation to EMU.

Moreover, and in contrast to 1997 , the credit rating became very important. The coefficient of the CREDIT variable, 8.81-significant at the $1 \%$ level, indicates that an improvement in the credit rating by one notch reduced the borrowing cost by 8.8 b.p..

As for the influence of maturity and the amount of issuance, both remained virtually unchanged: The coefficient of MATUR increased marginally from 7.72 to 8.81, and remained highly significant, while the coefficient of MATUR and of its logarithm were insignificant.

Providing some re-assurance about the reliability and robustness of the above 
results, neither the coefficients, nor their significance levels were affected by the inclusion of the time dummies, for both years. This also applies to the variable AMOUNT and its logarithm.

\section{Concluding Remarks}

Summarizing, Euro's introduction virtually eliminated the market segmentation due to the different currencies and, thus, led to a more integrated European bond market. It also reduced the segmentation due to the different countries. The latter, however, not only remained, but in addition became clearer in 1999 when the resolution of the uncertainty regarding EMU-participation accentuated the importance of the liquidity of the domestic markets. It remains to be seen whether this segmentation is further reduced as time goes by and investors become presumably more accustomed to the pan-European market.

In addition, Euro's introduction increased the role of credit ratings in the pricing of bonds. This should be taken into consideration by entities in countries that aspire to join E.M.U, for getting a good credit rating requires a substantial and lengthy preparation.

\section{Acknowledgement}

We thank Gikas Hardouvelis, Dimitrios Malliaropoulos and Nikitas Pittis for helpful comments on earlier drafts of the paper. Needless to say, we bear responsibility for all remaining errors.

Date accepted: May 2001

\section{References}

Antzoulatos, A.A. (2000). "On the Determinants and Resilience of Bond Flows to LDCs, 1990-1995", Journal of International Money and Finance, Vol. 19, pp. 399-418 (June).

Bank of England (1997-1999). The International Securities Markets.

Bank for International Settlements (BIS) (1999a). "Market Liquidity: Research Findings and Selected Policy Implications" (May).

Bank for International Settlements (BIS) (1999b). "Basel Committee on Banking Supervision A New Capital Adequacy Framework" (June). 
Cantor R. and F. Packer (1994). "The Credit Rating Industry” Federal Reserve Bank of New York Quarterly Review (Summer-Fall).

Cantor R. and F. Packer (1996). "Determinants and Impact of Sovereign Credit Ratings", Federal Reserve Bank of New York Quarterly Review (October).

Durbin E. and D.T.C. Ng (1999). "Uncovering Country Risk in Emerging Market Bond Prices", Board of Governors of the Federal Reserve System, International Finance Discussion Papers No. 639 (July).

Edwards, Sebastian (1984). "LDC Foreign Borrowing and Default Risk: An Empirical Investigation, 1976-1980”, American Economic Review, Vol. 75, No. 4, pp. 726-734. Eichengreen, Barry and Ashoka Mody (2000). "Lending Booms, Reserves and the Sustainability of Short-Term Debt: Inferences from the Pricing of Syndicated Bank Loans", Journal of Development Economics, Vol. 63, pp. 5-44.

EUROMONEY Research Guides: The 1999 Guide to Euro-denominated Securities; The 1999 Guide to European Bonds; The 1999 Guide to Italy.

European Commission (1997). The Impact of the Introduction of the Euro on Capital Markets.

Fitch IBCA (1998a). "Corporate Rating Analysis", Special Report (September 16).

Fitch IBCA (1998b). "Rating Above the Sovereign Ceiling”, Special Report (June 18).

Fitch IBCA (1998c). "The Rating Impact of the EU Monetary Union" (4 June).

Fitch IBCA (2000). "One Fewer Credit Risk for Euro" (May).

IMF (1999a). "Emerging Markets in the New Financial System: Nonstandard Responses to External Pressure and the Role of the Major Credit Rating Agencies in Global Financial Markets", chapter V in International Capital Markets.

IMF (1999b). "Use of Ratings in the Regulatory Process", Annex VI in International Capital Markets.

Larrain G., H. Reisen and J. Maltzan (1997). "Emerging Market Risk and Sovereign Credit Ratings", Technical Papers No.124, OECD Development Centre (April).

McKinnon R.I and H. Pill (1998). "International Overborrowing: A Decomposition of Credit and Currency Risks", World Development Vol.26, No.7, pp.1267-1282.

Merrill Lynch (2000). "Size and Structure of the World Bond Market:2000" (April).

STANDARD \& POOR'S (1997). "Financial System Stress and Sovereign Credit Risk", Sovereign Ratings Service (December).

STANDARD \& POOR'S (1999). "Sovereign Versus Corporate Ratings Stability", CreditWeek (September 29).

Stark, Jürgen (1999). "Mr. Stark Discusses How the Euro will Change the World of Finance", BIS Review 115/1999.

Treacy W.F. and M.S. Carey (1998). “Credit Risk Rating at Large U.S. Banks”, Federal Reserve Bulletin (November). 